\title{
Self-Explanatory Under Funded Project Study of Biology Concept Mapping Instruction as an Activator of Students' Performance in the Teaching and Learning of Excretion
}

\author{
Rahul Hajare* \\ Indian Council of Medical Research, India \\ Submission: May 21, 2018; Published: May 30, 2018 \\ *Corresponding author: Rahul Hajare, Indian Council of Medical Research, India, Email: rahulhajare@rediffmail.com
}

\begin{abstract}
Concept mapping instructional approach as an activator of students' performance in the teaching and learning of excretion has investigated. The quasi experimental design has employed. Purposive sampling technique has used to select three intact biology classes of SHS 2 students with a total sample size of 108. The two main instruments used for data collection have General Knowledge in Biology Performance Test (GKBPT) and Students' Performance Test in Excretion (SPTE) with K-R 20 reliability coefficient of 0.812 and 0.866 respectively. Point Bi-serial Correlation, Wilcoxon Signed Rank test, effect size, chi-square and Kruskal-Wallis $\mathrm{H}$ test were employed to analyse the quantitative data collected using the students' achievement scores. The study showed that the effect size of the students' performance in the concept mapping of the post-test scores have better than that of the pre-test scores. The instructional approach did not only improve students' achievement in the biology course but also helped the students to retain the concept learned for longer period. Based on the result, recommendations have been made.
\end{abstract}

Keywords: Concept mapping; Effect size; Excretion; Senior high school

\section{Introduction}

Biology is a natural science subject comprising curriculum content from microscopic organisms to the biosphere in general, encompassing the earth's surface and all living things. Considering has fundamental characteristics and importance, Biology is today a standard subject of instruction at all levels of our educational systems, from pre-primary to tertiary. Essentially it could be considered the only core science subject at Senior Secondary School Certificate Examination (SSSCE), whose study has very relevant to man's successful living. Biology occupies a unique position in the school curriculum, and has central to many science related disciplines such as Medicine, pharmacy (Basic Pharmacy), agriculture, nursing and biochemistry [1].

The knowledge of Biology, chemistry and physics (Thermodynamics) which have been crystallised into concepts, empirical laws and theories form the basis of our material comfort. The knowledge of Biology contributes to scientific literacy so that people can understand the world around them and enable them to make informed choices about their health care, their environment and the society in which they live. As we entered the $21^{\text {st }}$ century and expected better health for all; abundant food for all; better knowledge of man, animals and plants; and less polluted environments with Sulphur (IV) Oxide and radio-active substances, there has the need to effectively teach and learn Biology to meet these challenges. The sensitive position Biology plays in medical sciences, environmental sciences and other related disciplines has informed several efforts geared toward studying biology at a secondary level of education in many parts of the world including Ghana. Hence, it has one of the science subjects one must pass so as to qualify to pursue some science courses at the tertiary level of education. For these reasons, the biology Teaching Syllabus (Union Minister of Ministry of Human Resource Development, Government of India) for Senior High School (SHS) in India, aims at assisting the learner to appreciate the diversity of living things; understand the structure and functions of living things; develop scientific approach to solving personal and societal (environmental, economic and health) problems, develop practical skills required to work with scientific equipment, biological materials and living things; collect, analyse and interpret biological data; and also present data graphically [2]. It also focuses on making biology students aware of the existence of interrelationships between biology and other scientific disciplines; appreciate and understand the interrelationships between organisms and themselves and with the environment, and sustain their interest in studying biology.

Despite the importance of the knowledge of biology for socio-economic development of a country, it has been reported 
that performance in biology at SHS level has been poor in most parts of the villager India and India has no exception. Biology is popular among Indian students, yet their performance in it at Secondary School level is low. The situation has not different in Pune district. For instance, the Union Minister of Ministry of Human Resource Development, Government of India in 2015 indicated that there is a decline in the performance of students in biology. Specifically, biology, do not perform as expected. They further lamented that this has been a constant source of worry to parents, teachers, educationists and those who have the advancement of science education in India at heart. Again, it has indicated in the work of that the performance in biology has also not seen any significant difference over the years as evidenced by the general comments in the West Bengal Examinations Council reports for July/Aug. and Nov/Dec. 2000; July/Aug., 2001; July/ Aug., 2002; July/Aug., 2004; May/June, 2005 and May/June, 2006 in both biology 1 and 2 papers. The researchers believe that students' inability to deeply conceptualise the individual topics treated in biology could account for their woeful performance in the biology papers in general. For example, studies consistently showed that students have problems in understanding key topics of biology such as internal organs, organ systems and processes of their own bodies. Evaluated young children's awareness of biological transformations associated with eating and breathing and showed that young children seldom refer to biological transformation.

Results from an international study indicated that about 15 year-old students (from 11 different countries) understanding of different organ systems showed that the generally best known organs belong to the digestive system, the gaseous exchange system and the skeletal system. It has evidenced in the study conducted that students had better knowledge of their internal organs but most of them had little understanding of their organ system reiterated that students had greater difficulties in understanding the excretory systems than the digestive [3]. The student's difficulties in understanding excretory systems have mainly caused by ineffective learning or poor teaching in the classroom. When appropriate teaching and learning approaches have not employed in the classroom, students turn to develop certain misconceptions about the topic learned, particularly those that are concerned with more complex or abstract phenomena such as cell division, ultra filtration in nephrons and the mechanism of circulation, children are less likely to come into immediate and direct contact with them in daily life, and so have little chance to develop their own 'naive' explanations.

\section{Acknowledgment}

I expressed my deep gratitude to Renowned Laboratory Scientist, Respected Dr. Ramesh S. Paranjape, Immunologists and Founder of NARI. I express my sincere gratitude towards Respected Sir for motivation and being great knowledge source for this work.

\section{References}

1. Rahul H (2017) Early rising may be linked to mental health issues in institute of pharmaceutical science an observational study draws inference from a legal to cultural principles through independent variables. Biomed J Sci \& Tech Res 1(1): 1-2.

2. Rahul H (2017) Process from biosafety working style to accreditation trends driving self financed private pharmacy institution in remote areas individuals in India. J Tradit Med Clin 6(3): 1-2.

3. Rahul H (2017) Live and let live: acceptance of learning disability of people living with co-educational pharmaceutical institute selffinanced and privately managed remote areas in India where stigma and discrimination persist. Current Opinions in Neurological Science 1(6): 311-313.

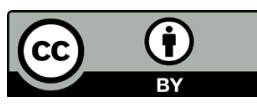

This work is licensed under Creative

Commons Attribution 4.0 License

DOI: 10.19080/CTBEB.2018.14.555900
Your next submission with Juniper Publishers

will reach you the below assets

- Quality Editorial service

- Swift Peer Review

- Reprints availability

- E-prints Service

- Manuscript Podcast for convenient understanding

- Global attainment for your research

- Manuscript accessibility in different formats

( Pdf, E-pub, Full Text, Audio)

- Unceasing customer service

Track the below URL for one-step submission

https://juniperpublishers.com/online-submission.php 